\title{
Soil-vegetation relationships on a banded ironstone 'island', Carajás Plateau, Brazilian Eastern Amazonia
}

\author{
JAQUELINAA. NUNES ${ }^{1}$, CARLOS E.G.R. SCHAEFER ${ }^{1}$, WALNIR G. FERREIRA JÚNIOR ${ }^{2}$, \\ ANDREZA V. NERI ${ }^{3}$, GUILHERME R. CORREA ${ }^{4}$ and NEAL J. ENRIGHT ${ }^{5}$
}

\footnotetext{
${ }^{1}$ Departamento de Ciências de Solos, Universidade Federal de Viçosa/UFV, Av. PH Rolfs, s/n, 36570-000 Viçosa, MG, Brasil ${ }^{2}$ Instituto Federal do Sul de Minas Gerais/IFSULDEMINAS, Câmpus Machado, Seção de Biologia, Rodovia Machado-Paraguaçu, Km 03, s/n, 37750-000 Machado, MG, Brasil

${ }^{3}$ Laboratório de Ecologia e Evolução de Plantas, Universidade Federal de Viçosa/ UFV, Av. PH Rolfs, s/n, 36570-900 Viçosa, MG, Brasil

${ }^{4}$ Instituto de Geografia, Universidade Federal de Uberlândia, Av. João Naves de Ávila, 2121, 38400-902 Uberlândia, MG, Brasil

${ }^{5}$ School of Veterinary and Life Sciences, Murdoch University, South Street, Perth, Western Australia, 6150, Australia
}

Manuscript received on March 5, 2014; accepted for publication on February 12, 2015

\begin{abstract}
Vegetation and soil properties of an iron-rich canga (laterite) island on the largest outcrop of banded-iron formation in Serra de Carajás (eastern Amazonia, Brazil) were studied along a topographic gradient (738$762 \mathrm{~m}$ asl), and analyzed to test the hypothesis that soil chemical and physical attributes play a key role in the structure and floristic composition of these plant communities. Soil and vegetation were sampled in eight replicate plots within each of the four vegetation types. Surface $(0-10 \mathrm{~cm})$ soil samples from each plot were analyzed for basic cations, N, P and plant species density for all species was recorded. CCA ordination analysis showed a strong separation between forest and non-forest sites on the first axis, and between herbaceous and shrubby campo rupestre on the second axis. The four vegetation types shared few plant species, which was attributed to their distinctive soil environments and filtering of their constituent species by chemical, physical and hydrological constraints. Thus, we can infer that Edaphic (pedological) factors are crucial in explaining the types and distributions of campo rupestre vegetation associated with ferruginous ironstone uplands (Canga) in Carajás, eastern Amazonia, therefore the soil properties are the main drivers of vegetation composition and structure on these ironstone islands.
\end{abstract}

Key words: Amazon Forest, canga, Carajás, ferruginous campo rupestre, iron formation, laterite.

\section{INTRODUCTION}

Banded iron formations (BIF) and associated ironstone landscapes are hotspots of plant diversity around the world (Gibson et al. 2012, Gledhill 1970, Porembski et al. 1994, Valentin et al. 1999, Vincent et al. 2002), supporting plant communities

Correspondence to: Carlos Ernesto G.R. Schaefer

E-mail: carlos.schaefer@ufv.br distinctive, both structurally and floristically from surrounding vegetation (Gibson et al. 2010, 2012, Jacobi et al. 2008, Yates et al. 2011a). In Brazil, campo rupestre refers to rupicolous (rocky habitat) vegetation that grows on a range of geologies, including quartzite-sandstone (Harley and Simmons 1986), granite-gneiss (Queiroz et al. 1996) and itabirite - an iron-rich metal sedimentary rock (Jacobi and do Carmo 2011, Jacobi et al. 
2007, Schaefer et al. 2009, Vincent and Meguro 2008). Semir (1991) considered campo rupestre to include any open vegetation type associated with rocky outcrops. Veloso et al. (1991) classified it as "vegetation refuges or relic vegetation types" floristically different from the dominant surrounding flora. Butcher et al. (2007) proposed that such areas have acted as refuges during dry climate phases associated with major glaciations, as well as centers of recent speciation.

In eastern Amazonia (Brazil), campo rupestre occurs on rocky habitat islands within a matrix of rainforest in the Serra dos Carajás and in the so-called Iron-Quadrangle of the state of Minas Gerais. These areas together comprise $97 \%$ of known iron ore reserves in Brazil (Porto and Silva 1989, Vincent et al. 2002). These ironstone substrates present a series of restrictions to plant establishment, including shallow and patchy soils (resulting in low water-retention capacities and low nutrient availability), high insolation levels, elevated temperatures, and the presence of potentially toxic metal concentrations (Meirelles et al. 1997, Silva and Rosa 1990). The topographic and edaphic characteristics of campo rupestre rock outcrops likely influence the floristic composition of their vegetation cover, as described for many rocky outcrop, environments elsewhere in the world (Gibson 2004a, b, Markey and Dillon 2008, Meissner and Caruso 2008, Porembski et al. 1994, Schaefer et al. 2009).

Four distinct vegetation types were considered as making up the campo rupestre complex on the ferruginous canga in our study, ranging from herbaceous campo rupestre and shrubby campo rupestre on rocky sites of the upper plateau (746$762 \mathrm{~m}$ asl), to capão forest and fringing montane forest at lower elevations and in the transition zone to lowland rainforest (738-742 $\mathrm{m}$ asl). Herbaceous campo rupestre is an open formation of small shrubs, with Vellozia glochidea (Velloziaceae) dominant over a ground layer of grasses; shrubby campo rupestre is supported on more fragmented canga that may allow greater root penetration, with the vegetation being composed of tall shrubs and herbaceous plants; capão forest is a semideciduous forest formation isolated as small islands within herbaceous campo rupestre and shrubby campo rupestre; montane forest is a dense ombrophilous forest located at the plateau edge in the transition (ecotone) between campo rupestre and the rainforests of the lower slopes of the Serra de Carajás.

Ferruginous campo rupestre vegetation in eastern Amazonia is subject to increasing loss due to iron-ore mining and land clearance for grazing. However, it is poorly studied relative to the surrounding rainforest matrix (Jacobi et al. 2007, 2008), even though recent work has indicated that open vegetation, comparable to campo rupestre, is widely distributed in eastern Amazonia (Schaefer et al. 2009). Given the poorly known floristic composition and potential loss of ferruginous campo rupestre, we studied the relationship between soil properties and floristic composition in a ferruginous campo rupestre habitat island in southeastern Pará State, Brazil. We hypothesized that variation in vegetation structure and composition is related to soil chemical and physical attributes. Specifically, we sought preliminary evidence that: (1) Forest patches on campo rupestre habitat islands differ in composition from surrounding lower montane forests, and that these differences may be due to strong soil chemical differences; (2) Differentiation of non-forest campo rupestre vegetation types may be driven by high concentrations of bioavailable metals (potentially toxic metals, e.g. Al, Fe, $\mathrm{Mn}$ ); and (3) Soil depth may be critical for the development of forest vegetation. 


\section{MATERIALS AND METHODS}

STUDY SITE

The study was located on a plateau of ironstone canga (lateritic capping) known as Serra Sul (738$762 \mathrm{~m}$ asl) in the Carajás National Forest (FLONA) conservation unit in southeastern Pará State, Brazil (Fig. 1). Ferruginous campo rupestre islands, cover approximately 9031 ha $(2.28 \%)$ of the total FLONA area of 395,827 ha.

The climate in the region is tropical, hot and humid (type "Aw" in the Köppen system; Ab'Saber 1986), with a dry season between May and October (average precipitation $<60 \mathrm{~mm}$ in the driest months), and a rainy season between November and April. Rainfall increases with altitude, with lowland areas receiving annual averages of 1500 $\mathrm{mm}$ and more elevated sites receiving up to 1900 mm/year (IBAMA et al. 2003). Average monthly temperatures vary between 19 and $31^{\circ} \mathrm{C}$.

The campo rupestre complex on ferruginous canga in Carajás, ranges from herbaceous campo rupestre and shrubby campo rupestre on rocky sites, to capão forest and fringing montane forest where the ironstone is fragmented and weathered to greater depth (Fig. 2).

\section{FIELD AND LABORATORY METHODS}

Soil and vegetation were sampled in eight replicate plots within each of the four vegetation types in July 2007. Because of major differences in vegetation structure between forest and non-forest areas, plot sizes and data collection methods varied accordingly (Mueller-Dombois and Ellenberg 1974). For forests (capão forest and montane forest), eight $100 \mathrm{~m}^{2}$ plots were located within each

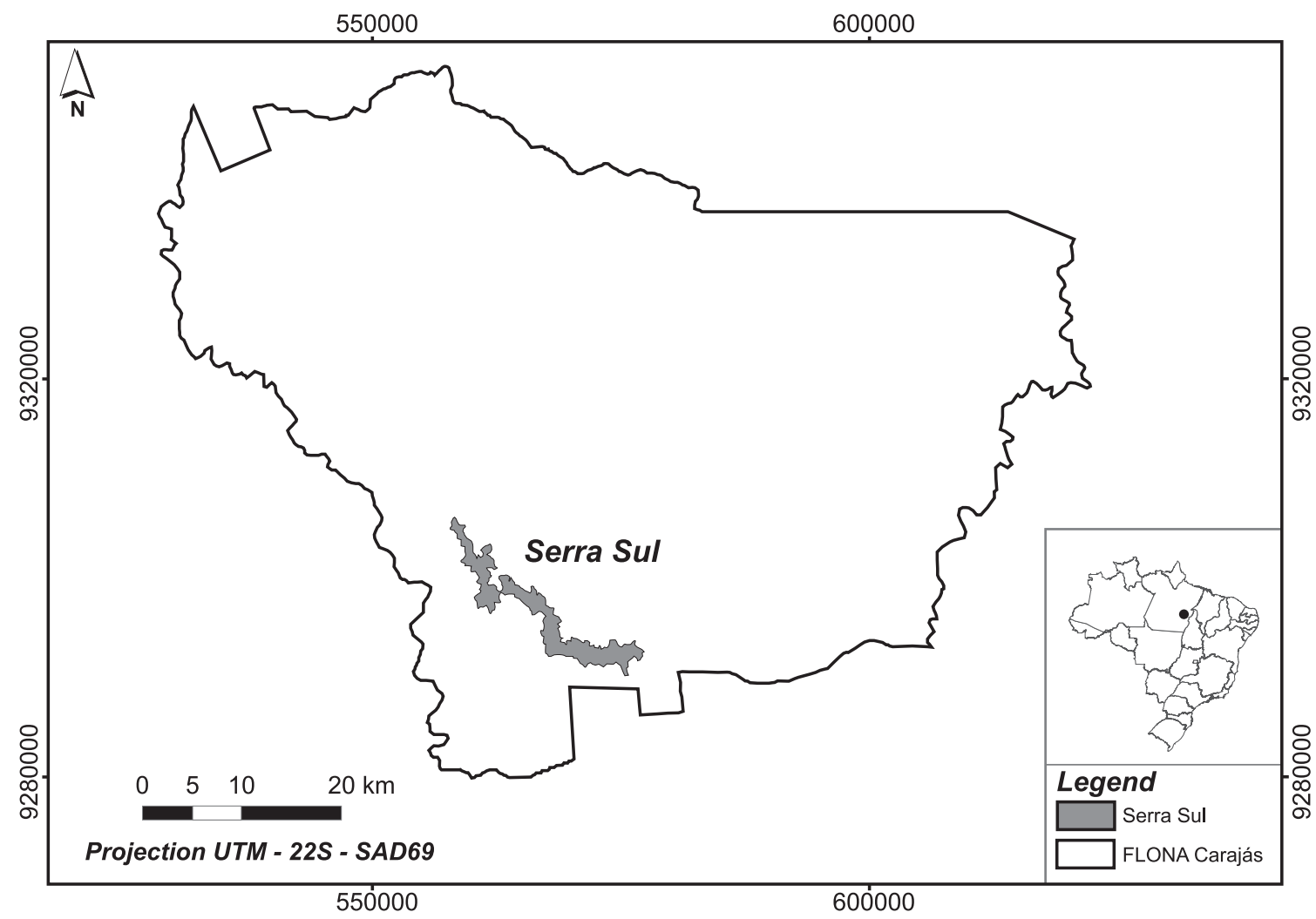

Figure 1. The study area, Serra Sul at Carajás National Forest, state of Pará is identified by dot on the inset map of Brazil. 


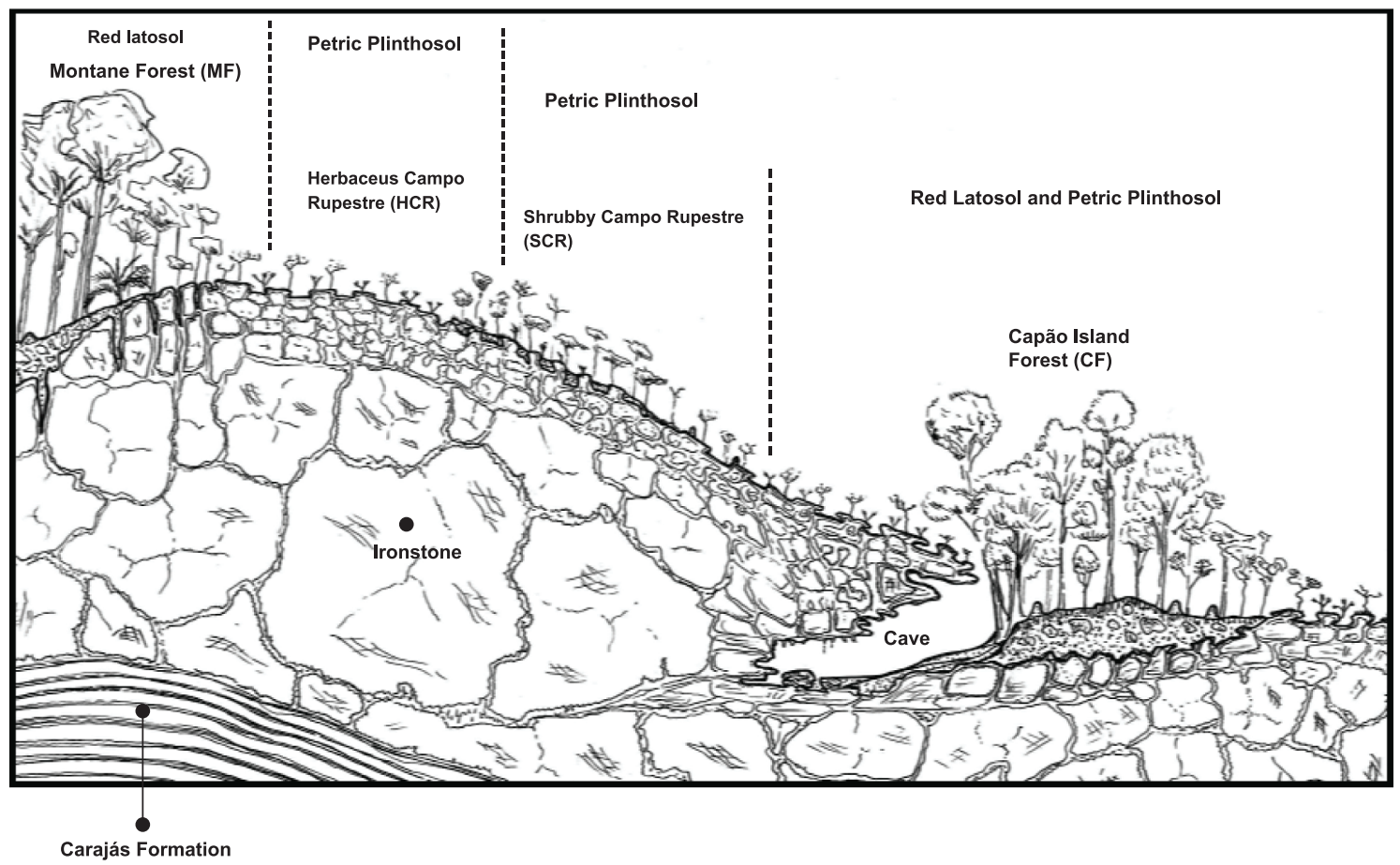

Figure 2. Profile diagram of vegetation and soils for the four different community types at National Forest Carajás, state of Pará, Brazil: herbaceous campo rupestre (HCR), shrubby campo rupestre (SCR), capão forest (CF), and montane forest (MF).

area, systematically in two rows of 4 plots, and all individuals with diameter at breast height (dbh) $\geq 3.2 \mathrm{~cm}$ were measured and identified. In shrubby campo rupestre, species identity were collected for all woody plants $>1 \mathrm{~cm}$ diameter at ground level in five $25 \mathrm{~m}^{2}$ plots located systematically, $(5 \mathrm{~m}$ apart) along eight transect lines, with data summed for each transect. In herbaceous campo rupestre, woody plant species abundances were determined for five random $1 \times 1 \mathrm{~m}^{2}$ quadrats at each of eight locations, with the data summed by location. Species identification was based on comparisons with previously identified material held at the Paraense Emilio Goeldi Museum Herbarium, and with the help of herbarium specialists.

For forest sites, three replicate $0.5 \mathrm{~L}$ surface soil (0-10 cm depth) samples were collected from each plot and bulked to provide one combined sample per plot, totaling eight soil combined samples in each forest area. For non-forest sites one sample was collected from the edge of each plot or quadrat $(\mathrm{n}=5)$ and bulked to provide one sample per transect (shrubby campo rupestre) or location (herbaceous campo rupestre). Soil effective depth (tolithic contact) was determined at each sampling location using a $1.5 \mathrm{~m}$ steel rod or from soil profile trenches dug for a previous study (Schaefer et al. 2009).

Soil samples were air-dried and sieved ( $2 \mathrm{~mm}$ mesh). All samples were stored in sealed glass jars and analyzed by the Soil Analysis Laboratory of the Soils Department at the Federal University at Viçosa, using international standard procedures (EMBRAPA 1997). The soil variables determined included, $\mathrm{pH}$ in $\mathrm{H}_{2} \mathrm{O}$ and in $\mathrm{KCl}$, extractable $\mathrm{P}$, $\mathrm{Na}, \mathrm{K}, \mathrm{Fe}, \mathrm{Zn}, \mathrm{Mn}, \mathrm{Cu}$ (by Mehlich 1extract), exchangeable $\mathrm{Ca}, \mathrm{Mg}$ and $\mathrm{Al}$ (extracted in $\mathrm{KCl}$ ), potential acidity $\mathrm{Al}+\mathrm{H}$ (extracted in calcium acetate at $\mathrm{pH} 7.0)$, organic carbon $(\mathrm{C}$; using the Walkley-Black method), $\mathrm{P}$ remaining in solution 
(P-res) - a proxy of P-adsorption capacity, and composite measures including sum of bases (BS= $\mathrm{Ca}+\mathrm{Mg}+\mathrm{K}+\mathrm{Na}$ ) and total cation exchange capacity (CEC).

\section{DATA ANALYSES}

To examine the significance of differences between the chemical and physical characteristics of soils among the four sample areas, one-way analysis of variance (ANOVA) was used, followed by Tukey's post-hoc comparison of means test (Zar 1996). All data were tested for normality and homogeneity, and transformed as necessary ( $\mathrm{P}$ was transformed to meet normality requirements; all other variables had skewness within \pm 1.5 ). A significance level of $\mathrm{p}<0.05$ was adopted. Analyses were conducted using Statistica 6 (StatSoft Inc 2003).The soil data were screened for strongly inter-correlated variables, and where $\mathrm{r}$ was $>0.9$ between any two variables, one was dropped (dropped variables were; $\mathrm{H}+\mathrm{Al}=$ Potential Acidity; $\mathrm{BS}=$ Total exchangeable bases; $\mathrm{V}=$ Base Saturation Index; $\mathrm{t}$ $=$ Effective Cation Exchange Capacity; $\mathrm{T}=$ Cation Exchange Capacity at $\mathrm{pH} 7.0 ; \mathrm{m}=$ Aluminum Saturation Index; ISNa = Sodium Saturation Index) from subsequent analyses.

A canonical correspondence analysis (CCA) ordination was conducted to analyse the correlation between environmental variables and species abundances (ter Braak 1987). The abundance values were transformed to $\ln +1$, because species of smaller life forms tended to be much more abundant than woody species. Species with plot density $<5$ were excluded from the CCA since rare species can increase the total inertia of the species dataset (ter Braak and Šmilauer 2002). Thus, the vegetation matrix comprised the 127 most abundant species (Table SI - Supplementary Material), while the main environmental matrix was formed using all soil variables meeting the inter-correlation criteria described above.
A second environmental matrix contained information on the geographic distance between all pairs of plots. Monte Carlo permutation tests were used to verify the significance levels of the results presented by the principal axis of the canonic ordination, which enable us to evaluate the statistical significance of the relationships encountered between the community variables and the environmental variables (ter Braak 1994). CCA was run using PC-ORD version 6 (McCune and Mefford 2011).

To examine what proportion of the variance in the vegetation composition data was attributable to soil chemistry and soil depth, we used the variance partitioning methods of Borcard et al. (2011) by partial Redundancy Analysis (Peres-Neto et al. 2006). The biotic dataset was transformed using Hellinger transformation (Peres-Neto and Legendre 2010). The Hellinger transformation is recommended when species abundance data are used (Legendre and Gallagher 2001), since it gives a more accurate, unbiased estimate of variance partition (Peres-Neto et al. 2006). Because the VIF (Variance inflation factor) of 12 was high (a common rule is that values over 10 indicate redundant constraints; Oksanen et al. 2011), the bases sum variable was dropped. Results of partial Redundancy Analysis were based on adjusted fractions of variation (Peres-Neto et al. 2006). The total variation in species composition was divided into four fractions; [a] variation explained by a group of soil chemical variables including $\mathrm{P}, \mathrm{K}, \mathrm{Na}, \mathrm{C}$, Pres and $\mathrm{Al}$; [b] variation that is shared between the two soil variable groups; [c] variation explained by the second soil variables group, comprising soil depth and $\mathrm{pH}$; and [d] the unexplained variance. All analyses were run using $\mathrm{R}$ functions (R Development Core Team 2011) available in vegan (Oksanen et al. 2011).

Plant species observed richness (S), Jackknife 2 and Chao 2 estimated richness were calculated separately for montane forest, capão forest, 
herbaceous campo rupestre and shrubby campo rupestre. These richness estimators provide an estimate of the true species richness of the sampled vegetation, based on the frequency of species occurring once or twice only, in the set of samples collected, allowing assessment of likely differences in total species richness among the four vegetation types, and the adequacy of the different plot sizes and sampling procedures used here for describing each vegetation type (McCune and Grace 2002). Chiarucci et al. (2003) found the Jackknife 2 to be the best available richness estimator based on faster approach to total richness and lowest under estimation rate at small sample size, while Chao 2 tended to under estimate total species richness.

\section{RESULTS}

All soils were strongly acidic, low in available $P$ and high in extractable Fe (Table I). Nevertheless, there were significant differences between soil properties among the sample areas for these and for other soil physical and chemical properties (Table I).

The CCA ordination showed a clear trend in soil properties from forest to non-forest sites on axis I. Soil depth and $\mathrm{pH}$ were greater in forests (montane forest and capão forest), while $\mathrm{Fe}+$, organic carbon and most base cations showed higher values in the non forest sites (Fig. 3). Plots with positive scores on Axis 1 were all in campo rupestre (shrubby campo rupestre and herbaceous campo rupestre) with shallow soils. Axis 2 further separated the four physiognomies, where nonforest sites showed higher plot dispersion and edaphic conditions distinct from the others sites. Montane forest showed higher $\mathrm{pH}$, and capão forest and montane forest had greater soil depths than those found for shrubby and herbaceous campo rupestre. Herbaceous campo rupestre showed a high correlation with $\mathrm{K}$ and $\mathrm{Mg}$, while shrubby campo rupestre was strongly correlated with

TABLE I

Mean soil variable concentrations ( $\pm 95 \%$ C.I.) for surface soils $.0-10 \mathrm{~cm}$. by vegetation type on lateritic canga at Serra Sul, Serra dos Carajás, state of Pará, Brazil. SCR = shrubby campo rupestre; $\mathrm{HCR}=$ herbaceous campo rupestre; $\mathrm{CF}=$ capão forest; $\mathrm{MF}=$ montane forest. Row values (vegetation groups) followed by the same letter are not significantly different (ANOVA with post-hoc Tukeys test; $\mathbf{p}<\mathbf{0 . 0 5}$ ).

\begin{tabular}{ccccc}
\hline Soil variables & HCR & SCR & CF & MF \\
\hline $\mathrm{pH}$ & $4.3 \pm 0.1 \mathrm{a}$ & $4.3 \pm 0.1 \mathrm{a}$ & $3.7 \pm 0.1 \mathrm{~b}$ & $4.5 \pm 0.04 \mathrm{c}$ \\
$\mathrm{P}\left(\mathrm{mg} / \mathrm{dm}^{3}\right)$ & $2.2 \pm 0.3 \mathrm{a}$ & $1.7 \pm 0.4 \mathrm{a}$ & $7.5 \pm 3.8 \mathrm{~b}$ & $3.8 \pm 0.1 \mathrm{c}$ \\
$\mathrm{K}\left(\mathrm{mg} / \mathrm{dm}^{3}\right)$ & $68.7 \pm 7.5 \mathrm{~b}$ & $88.6 \pm 11.6 \mathrm{a}$ & $27.5 \pm 3.4 \mathrm{c}$ & $57.4 \pm 6.6 \mathrm{~d}$ \\
$\mathrm{Na}\left(\mathrm{mg} / \mathrm{dm}^{3}\right)$ & $13.4 \pm 2.9 \mathrm{a}$ & $14.2 \pm 3.1 \mathrm{a}$ & $7.6 \pm 3.0 \mathrm{~b}$ & $5.5 \pm 0.8 \mathrm{~b}$ \\
$\mathrm{Ca}\left(\mathrm{cmolc} / \mathrm{dm}^{3}\right)$ & $1.15 \pm 0.53 \mathrm{~b}$ & $0.64 \pm 0.38 \mathrm{a}$ & $0.02 \pm 0.02 \mathrm{c}$ & $0.06 \pm 0.03 \mathrm{c}$ \\
$\mathrm{Mg}\left(\mathrm{cmolc}^{3} \mathrm{dm}^{3}\right)$ & $0.37 \pm 0.10 \mathrm{a}$ & $0.51 \pm 0.09 \mathrm{a}$ & $0.05 \pm 0.01 \mathrm{~b}$ & $0.30 \pm 0.15 \mathrm{a}$ \\
$\mathrm{Al}\left(\mathrm{cmolc} / \mathrm{dm}^{3}\right)$ & $1.0 \pm 0.2 \mathrm{~b}$ & $1.7 \pm 0.1 \mathrm{a}$ & $2.3 \pm 0.1 \mathrm{c}$ & $1.8 \pm 0.1 \mathrm{a}$ \\
$\mathrm{BS}\left(\mathrm{cmolc} / \mathrm{dm}^{3}\right)$ & $1.9 \pm 0.6 \mathrm{~b}$ & $1.4 \pm 0.3 \mathrm{a}$ & $0.2 \pm 0.1 \mathrm{c}$ & $0.6 \pm 0.3 \mathrm{~d}$ \\
$\mathrm{Organic} \mathrm{C}(\%)$ & $42.8 \pm 6.9 \mathrm{~b}$ & $28.3 \pm 4.2 \mathrm{a}$ & $6.9 \pm 0.8 \mathrm{c}$ & $8.2 \pm 1.6 \mathrm{c}$ \\
$\mathrm{P} \mathrm{Res}(\mathrm{mg} / \mathrm{L})$ & $28.2 \pm 1.9 \mathrm{~b}$ & $20.5 \pm 5.2 \mathrm{a}$ & $11.4 \pm 1.2 \mathrm{c}$ & $12 \pm 1.4 \mathrm{c}$ \\
$\mathrm{Zn}\left(\mathrm{mg} / \mathrm{dm}^{3}\right)$ & $1.7 \pm 0.3 \mathrm{~b}$ & $1.3 \pm 0.1 \mathrm{a}, \mathrm{b}$ & $0.8 \pm 0.4 \mathrm{a}$ & $0.9 \pm 0.1 \mathrm{a}$ \\
$\mathrm{Fe}\left(\mathrm{mg} / \mathrm{dm}^{3}\right)$ & $898 \pm 101 \mathrm{a}$ & $982 \pm 59 \mathrm{a}$ & $429 \pm 151 \mathrm{~b}$ & $149 \pm 18 \mathrm{c}$ \\
$\mathrm{Mn}\left(\mathrm{mg} / \mathrm{dm}^{3}\right)$ & $9.9 \pm 3.2 \mathrm{~b}$ & $5.8 \pm 1.1 \mathrm{a}$ & $1.1 \pm 0.1 \mathrm{c}$ & $7.6 \pm 0.8 \mathrm{a}, \mathrm{b}$ \\
$\mathrm{Cu}\left(\mathrm{mg} / \mathrm{dm}^{3}\right)$ & $0.49 \pm 0.05 \mathrm{a}$ & $0.52 \pm 0.11 \mathrm{a}$ & $0.37 \pm 0.11 \mathrm{~b}$ & $0.55 \pm 0.07 \mathrm{a}$ \\
$\mathrm{Depth}\left(\mathrm{cm}^{3}\right)$ & $8.7 \pm 2.6 \mathrm{~b}$ & $38.4 \pm 5.1 \mathrm{a}$ & $93.1 \pm 9.6 \mathrm{c}$ & $113.7 \pm 12.9 \mathrm{c}$ \\
\hline
\end{tabular}




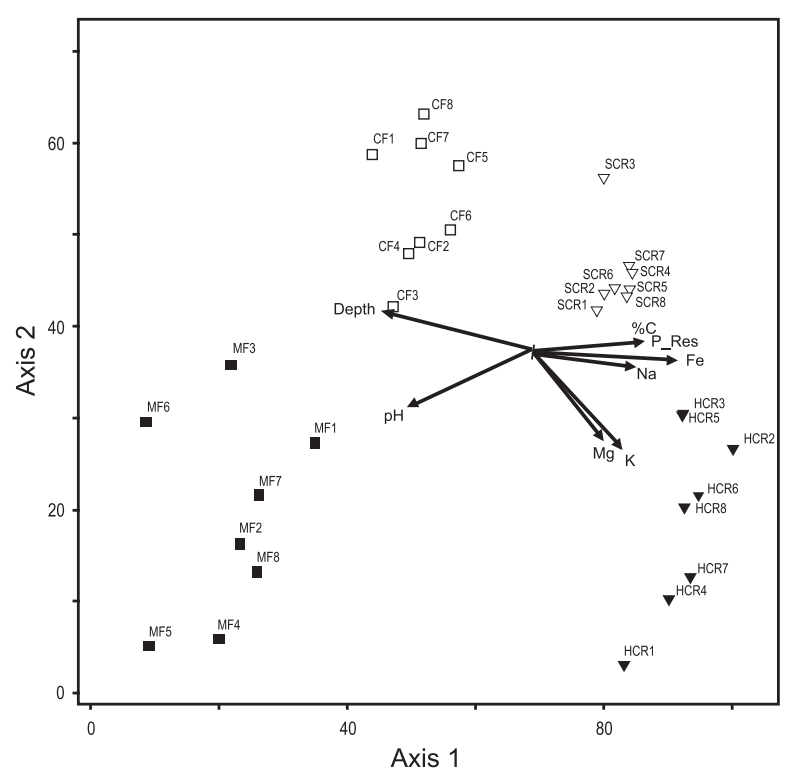

Figure 3. A canonical correspondence analysis (CCA) ordination of environmental variables and species abundance for plots from the four vegetation types at Serra Sul, Serra dos Carajás, Pará State, Brazil: herbaceous campo rupestre (HCR), shrubby campo rupestre (SCR), capão forest (CF), and montane forest (MF).

organic matter and residual phosphorus (P-res). Overall, soil properties were most distinctive in capão forest with higher available $\mathrm{P}$ and $\mathrm{Al}$, and lower pH, K, Ca, Mg, Mn, Zn, Cu, BS, C, and P-res (Table I). There was a clear separation between open vegetation and forested areas, with strongly differentiated species groups associated with each of the four physiognomies (Fig. 4).

The variables that demonstrated the highest positive correlations on the first CCA axis were extractable iron and soil organic matter. Soil depth and $\mathrm{pH}$ had the highest negative correlations, while aluminum also demonstrated a negative correlation. There was a negative correlation with potassium and magnesium on the second axis and a positive correlation with phosphorus (Fig. 3 and Table II; Fig. 4).

The eigenvalues obtained in the CCA ordination of the soil chemical variables for the three axes can be considered high $(>0.5)$ (ter Braak 1995) (Table II). The three axes explained 11.2\%

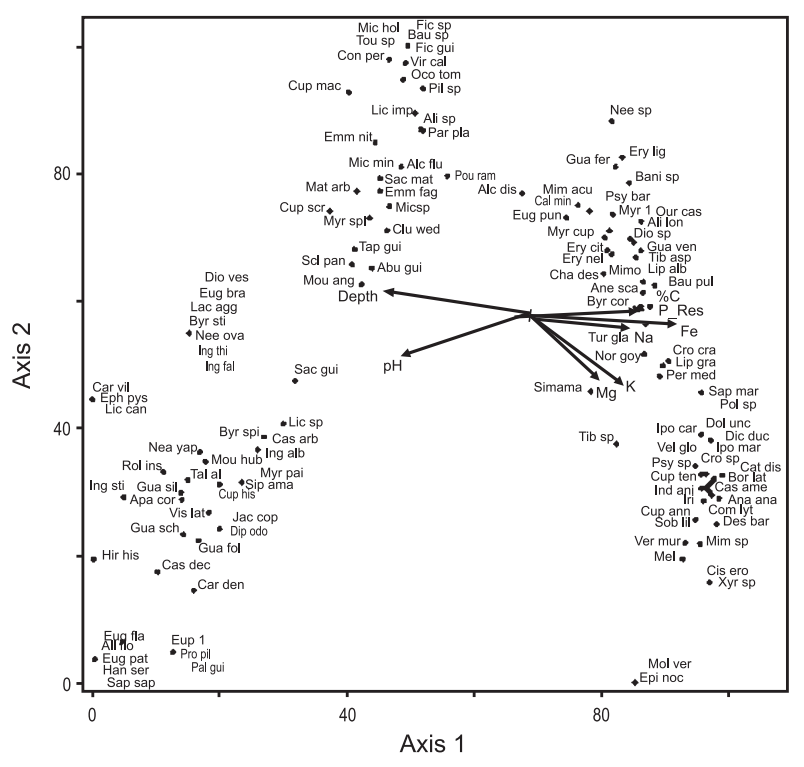

Figure 4. Canonical correspondence analysis (CCA) ordination of environmental variables and species abundance for the four vegetation types at Serra Sul, Serra dos Carajás, state of Pará, Brazil: herbaceous campo rupestre, shrubby campo rupestre, capão forest, and montane forest.

(axis 1), 7.7\% (axis 2), and 7.1\% (axis 3) of the variation, summing up to a total accumulated or global variance of $26 \%$. In spite of the fact that the accumulated values were low, the speciesenvironment relationships were not compromised, since the CCA produced high correlation values between the species and the environmental variables (Table II). Vellozia glochidea, Dyckia duckei, Sobralia liliastrum and Psychotria sp. were associated with shallow soils, high cover of bare rock and higher content of $\mathrm{Mg}$ and $\mathrm{K}$ in the surface soil, while Callisthene minor, Bauhinia pulchella, Alibertia longiflora and Mimosa acutistipula were related to soil with higher Fe content, phosphorus residual and organic carbon (Fig. 4). These species had higher cover on non-forests sites. Myrcia splendens, Saccoglottis mattogrosensis, Pouteria ramiflora, Pilocarpus sp. and Sclerolobium paniculatum were strongly associated with forests (Fig. 4). Mouriri huberi and Neea yapurensis had 
TABLE II

Summary of canonical correspondence analysis (CCA) of plant species coverage and soil properties for the studied rocky outcrops on lateritic canga at Serra Sul, Serra dos Carajás, state of Pará, Brazil.

\begin{tabular}{cccc}
\hline & Axis 1 & Axis 2 & Axis 3 \\
\hline Eigenvalues & 0.873 & 0.601 & 0.548 \\
Percentage of explained variance & 11.2 & 7.7 & 7.1 \\
Percentage of cumulative variance & 11.2 & 19.0 & 26.0 \\
\hline Correlations of the Internal Variables & & & \\
\hline $\mathrm{pH}$ & -0.795 & -0.357 & -0.090 \\
$\mathrm{P}$ & -0.397 & 0.448 & -0.375 \\
$\mathrm{~K}$ & 0.576 & -0.640 & 0.280 \\
$\mathrm{Na}$ & 0.654 & -0.093 & 0.203 \\
$\mathrm{Ca} 2+$ & 0.538 & 0.006 & 0.400 \\
$\mathrm{Mg} 2+$ & 0.494 & -0.589 & 0.305 \\
$\mathrm{Al3}+$ & -0.490 & 0.011 & -0.707 \\
$\mathrm{SB}$ & 0.597 & -0.147 & 0.500 \\
\%C & 0.706 & 0.071 & 0.584 \\
$\mathrm{P}$ Res & 0.678 & 0.070 & 0.527 \\
$\mathrm{Zn}$ & 0.542 & 0.026 & 0.455 \\
$\mathrm{Fe}$ & 0.906 & 0.058 & 0.164 \\
$\mathrm{Mn}$ & 0.222 & -0.194 & 0.680 \\
$\mathrm{Depth}$ & -0.935 & 0.248 & -0.027 \\
\hline & & &
\end{tabular}

greatest coverage where soils were deeper and they were negatively related to $\mathrm{pH}$.

Approximately $43 \%$ of the variation in species composition was explained by two environmental (soil) variable groups (Fig. 5). Both the first [a] and second [c] group fractions were significant $(p<0.005)$. The second environmental variables group (soil depth and $\mathrm{pH}$ ) showed higher variation than the first group (P, K, Na, C, P-res and Al), explaining $29 \%$ and $2 \%$ respectively, with the shared component [b] explaining a further $12 \%$.

Observed sample species richness $\left(\mathrm{S}_{\text {obs }}\right)$ was highest for montane forest (49 species), followed by capão forest, shrubby campo rupestre and herbaceous campo rupestre, respectively (Table III). Total estimated species richness based on the Jackknife 2 and Chao 2 estimators showed the same order as observed species richness (S), but with much larger differences in absolute richness indicating many more unsampled species for montane forest and capão forest than for shrubby campo rupestre and herbaceous campo rupestre vegetation (Table III).

\section{DISCUSSION}

With reference to hypotheses 1 and 2 raised in this study, diverse terminologies have been used previously to describe the (mostly shrubby) vegetation growing on ferruginous laterites (canga) in eastern Amazonia. They have been classified as Canga Vegetation (Morelato and Rosa 1991, Secco and Mesquita 1983, Silva 1992), Banded Ironstone Formations - BIF (Page 2001), ferruginous campo rupestre (Jacobi et al. 2007, 2008, Rizzini 1979, Vincent and Meguro 2008), and even Metallophile Savanna (Porto and Silva 1989). The plant species 


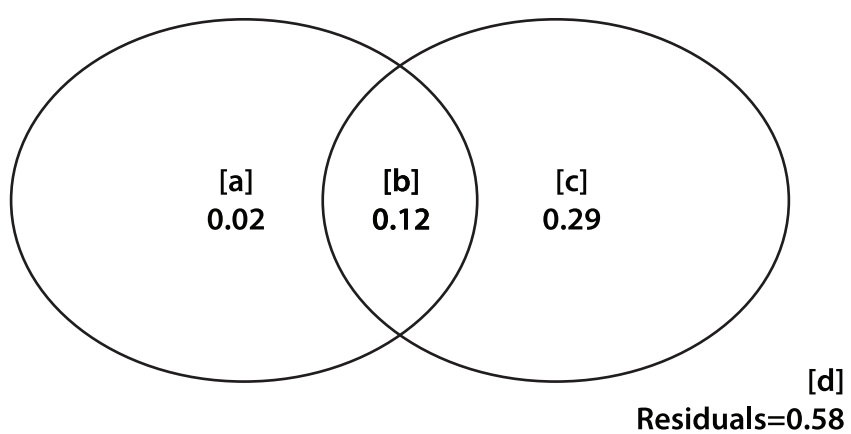

Figure 5. Variation partitioning for the Serra Sul vegetation data explained by two soil variable groups based on a partial Redundancy Analysis. Values shown are adjusted $\mathrm{R}^{2}$. The first soil group [a] comprises environmental variables $\mathrm{P}, \mathrm{K}, \mathrm{Na}, \mathrm{C}$, Pres, $\mathrm{Al}$, and the second group [c] the variables soil depth and $\mathrm{pH}$. Variation that is shared between two environmental variables groups is shown by [b], and the unexplained variance by [d]. Fractions were significant at $\mathrm{p}<0(005)$.

TABLE III

Observed $\left(\mathrm{S}_{\mathrm{obs}}\right)$ and estimated plant species richness (second-order Jackknife, $J_{2}$, and Chao estimators) for each of the four vegetation types sampled on lateritic canga at Serra Sul, state of Pará, Brazil( Error term for Chao 2 is standard deviation of the bias corrected estimate.

\begin{tabular}{cccc}
\hline Vegetation type & $\mathbf{S}_{\text {obs }}$ & $\mathbf{J}_{\mathbf{2}}$ & Chao 2 \\
\hline MF & 49 & 84 & $71 \pm 11$ \\
CF & 41 & 61 & $52 \pm 7$ \\
SCR & 39 & 54 & $49 \pm 8$ \\
HCR & 36 & 42 & $38 \pm 2$ \\
\hline
\end{tabular}

found growing there often show dwarfing (Porto and Silva 1989) and some can retain high concentrations of metals in their tissues (Teixeira and LemosFilho 1998, Vincent 2004). These high soil-metal concentrations may lead to the selection of tolerant individuals in these environments (Porto and Silva 1989), resulting in vegetation that is structurally and floristically distinct from the surrounding vegetation matrix. Regardless of differences between soil variables for the four areas sampled here, all were acidic and had low phosphorus levels; as results found in other studies in ironstone (Markey and Dillon 2008, 2009, 2010, Meissner et al. 2009, Meissner and Wright 2010, Messias et al. 2013, Teixeira and Lemos-Filho 2002, Vincent and Meguro 2008). According to Jacobi and do Carmo
(2011), the comparison of open areas with forest islands, subjected to the same climatic conditions, shows the important influence of edaphic and microclimatic conditions in determining lifeform spectra and species composition in these plant communities. The isolation of the edaphic environments of inselbergs, produce endemic species, or species with distributions restricted largely to these conditions (Porembski et al. 1994), resulting in vegetation that is structurally and floristically distinct from the surrounding forest matrix, as reported by Viana and Lombardi (2007).

Soil extractable Fe and bioavailable Al were markedly higher in capão forest than in fringing montane forest, and $\mathrm{Al}$ was higher in herbaceous campo rupestre than in shrubby campo rupestre. High concentrations of Al can be toxic to plants, but high levels of soil carbon can reduce the potentially toxic effects of high concentrations of $\mathrm{Al}$ (Barros 1979), and this may provide amelioration of potential toxicity effects in herbaceous campo rupestre. Similarly, although Al concentrations are high for surface soil in capão forest, most of the nutrient cycling here is associated with the litter layer rather than with the mineral soil. Melichextractable Fe concentrations were high in all sites, with highest levels found in the non-forest campo rupestre sites. The values for extractable Fe 
found here are higher than those reported by Silva (1992) for hematite-rich canga in Serra Norte, Carajás, and by Vincent and Meguro (2008) in the Iron-Quadrangle of Minas Gerais, but there is no evidence to suggest that these high levels for extractable $\mathrm{Fe}\left(\right.$ such as $\mathrm{Fe}^{2+}$ ) are driving vegetation differences among sites, since most $\mathrm{Fe}$ is present in soil as $\mathrm{Fe}^{3+}$, being insoluble and non-available. This indicates that seasonal reducing conditions occur in campo rupestre sites, increasing the amount of $\mathrm{Fe}^{2+}$ released from $\mathrm{Fe}$-oxide dissolution. Therefore, while hypothesis 1 is supported by the data presented here, hypothesis 2 is not, and further work on the effective role of high metal concentrations is recommended.

Botrel et al. (2002) reported that areas with dry soils and low chemical fertility tend to only have a few ecologically dominant species, but in our study, observed species richness was generally high throughout (Table II). Nevertheless, based on species richness estimators, total species richness was much higher in the extensive fringing montane forest, and in capão forest, than in the non-forest vegetation of the lateritic canga (Table III). Overall, a sample size was adequate for the two campo rupestre vegetation types, but was too small to accurately represent species richness for forest sites, especially for montane forest. In addition, the four vegetation types held few species in common, suggesting strong edaphic filtering from the available plant species pool, acting most strongly in the campo rupestre vegetation types. While floristic composition of fringing montane forests is likely to be strongly influenced by the composition of the extensive rainforest around them, the composition of the capão forest and campo rupestre sites may represent floras more specialized to the environmental filters associated with these ironstone habitat islands (Viana and Lombardi 2007). Vincent and Meguro (2008) reported a distinct separation of physiognomic groups based on their absolute species densities and soil variables in a study in the Iron Quadrangle, Brazil.

According to Forza et al. (2012), most of the species found in montane forest are widely distributed in Amazonian rainforest, including Allophyllus floribundus, Cupania hispida, Dipterix odorata, Eugenia brachypoda, Eugenia patrisii, Guatteria foliosa, Inga stipulacea, Inga falcistipula, Nealchornea yapurensis, Vismia latifolia and Myrcia paivae. In contrast, while some species in capão forest are also found in other Brazilian biomes (e.g. Sacoglottis mattogrossensis, Myrcia splendens, Sclerolobium paniculatum, Matayba arborescens and Tapirira guianensis), many are unique to this vegetation type in the Amazonia area, including Licania impressa, Alchornea fluviatilis, Connarus perrottetii, Cupania macrophylla, Emmotum fagifolium, Mouriri angulicosta, Ocotea tomentela, and Virola callophylla. Capão forest also holds some species in common with the nonforest campo rupestre (Callisthene minor, Eugenia punicifolia, Pouteria ramiflora and Myrcia cuprea), as also found by Viana and Lombardi (2007).

The non-forest vegetation (shrubby campo rupestre and herbaceous campo rupestre) at Carajás comprises a mix of widely distributed and locally endemic plant species. Several species are shared with the Brazilian Cerrado biome (e.g. Chamaecrista desvauxi, Anemopaegma scabriusculum, Lippia alba, Norantea goyazensis, Guapira ferruginea, Pouteria ramiflora, Callisthene minor) and Caatinga (e.g. Pilosocereus sp., Mimosa acutistipula, Periandra mediterranea, Eugenia punicifolia, Polygala sp.), while a few (including Erythroxylum nelson-rosae, Ipomoea marabaensis, Ipomoea carajasensis, Ipomoea cavalcantei plus two varieties of Mimosa and one of Erythroxylum) are restricted solely to ferruginous habitats in Carajás. However, ongoing studies (Schaefer et al. 2009, J. Nunes, unpublished data) indicate that many species considered ironstone lovers (e.g. Vellozia glochidea) are widely distributed across 
open vegetation supported by different lithologies in this region, not just ironstone outcrops. Overall, the species composition of vegetation types of the banded-iron canga islands is unique and shows very high beta diversity, reflecting a high diversity of habitats defined by soil physical and chemical properties. The high conservation value of these habitat islands, and their potential loss through anthropogenic impacts, requires urgent conservation management action.

In the present study, chemical and physical soil attributes had a role beyond the definition of different phytophysiognomies, also affecting species composition. For the latter, the environmental partitioning model explained $43 \%$ of the observed variance. Soil variables [environmental matrix c], including $\mathrm{pH}$ and soil depth, provided the greatest contribution explain species composition, while combined soil chemical and physical properties also contributed in explaining the species distribution patterns observed. Differences in soil chemical attributes allowed clear separation of the campo rupestre sites, whereas soil depth appears to be a key factor for the establishment and development of the forest sites, supporting hypothesis 3.

Schaefer et al. (2009) noted that soil depth seemed to play a fundamental role in the definition of the phytophysiognomies seen in the Carajás Plateaus, which is supported in the present study by the relationships observed for soil depth in differentiating forest (deeper soils) and non-forest areas (shallower soils) wherein, shrubby (deeper) and herbaceous (shallower) campo rupestre on the other. There is a clear vegetation gradient from herbaceous campo rupestre to montane forest accompanying the gradient of soil depth: herbaceous campo rupestre $<$ shrubby campo rupestre $<$ capão forest $<$ montane forest. Yates et al. (2011b) similarly identified species habitat preferences associated with soil depth for bandediron plant communities in Western Australia.
Despite their shallowness, non-forest (herbaceous campo rupestre and shrubby campo rupestre) soils have higher surface $(0-10 \mathrm{~cm})$ organic matter levels than forest soils, probably due to the presence of charred organic matter produced by frequent fire. Fire may be an important environmental filter contributing to the floristic and structural differences in the vegetation. Furthermore, higher termite activity in the campo rupestre sites may also contribute to higher levels of surface soil organic carbon through redistribution of organic-rich materials (Schaefer et al. 2009). In Sarcinelli et al. (2009), studies of the influence of termite activity on soil characteristics in Minas Gerais, their concluded that high concentrations of $\mathrm{C}, \mathrm{P}$ and nutrients in termite mounds (in relation to the surrounding soils) were associated with the active incorporation of organic material during construction of the termite mounds. The higher organic matter in herbaceous campo rupestre may also be attributed to lower water availability and slower organic matter decomposition, and to differences in the soil fauna available for organic matter processing.

Thus, we can infer that Edaphic (pedological) factors are crucial in explaining the types and distributions of campo rupestre vegetation associated with ferruginous ironstone uplands (Canga) in Carajás, eastern Amazonia. Four ferruginous vegetation types were identified, each with distinct soil physical and chemical, and floristic and structural, characteristics. Vegetation differences were associated with variations in soil chemistry, depth and acidity. Forest soils showing greater depths and higher concentrations of $\mathrm{P}$ and $\mathrm{Al}$, but much lower levels of organic matter and exchangeable cations at the surface, reflecting major differences in nutrient cycles between forest and non-forest sites. The higher nutrient and organic carbon contents in campo rupestre may be indirectly associated with frequent fire, filtering the species that are able to persist through recurrent 
fire events. Soil organic matter content is also likely a key variable for the development of the phytophysiognomies studied, especially in the camporupestre, wheremostofthe inorganic nutrients were correlated with organic matter (carbon) amounts in the topsoil. High Fe concentrations do not appear to restrict the establishment of species in the different phytophysiognomies, as this element was found in similar amounts throughout the study area. As such, the use of the term metal-loving Savanna (or Metallophile Savanna) does not appear appropriate for the ironstone canga vegetation or campo rupestre at Carajás, and we suggest the use of the term ferruginous campo rupestre complex for the herbaceous and shrubby campo rupestre formations.

\section{ACKNOWLEDGMENTS}

Prof. Carlos Schaefer thanks Coordenação de Aperfeiçoamento de Pessoal de Nível Superior (CAPES) for funding a Senior Sabbatical leave at University of Cambridge-UK. We thank the Fundação de Amparo a Pesquisa de Minas Gerais (FAPEMIG) and Conselho Nacional de Desenvolvimento Científico e Tecnológico (CNPq) for the scholarship to Jaquelina Alves Nunes, and thank the Vale Company for all logistic support. We thank two anonymous reviewers for their helpful suggestions. This work was conducted at the Universidade Federal de Viçosa, Minas Gerais, Brazil.

\section{RESUMO}

Vegetação e propriedades do solo de uma ilha de canga rica em ferro (laterita) no maior afloramento de formação ferrífera bandada, na Serra de Carajás (Amazônia oriental, Brasil), foram estudados, ao longo de um gradiente topográfico $(738-762 \mathrm{~m}$ de altitude), e analisados para testar a hipótese de que os atributos químicos e físicos do solo desempenham um papel fundamental na estrutura e composição florística destas comunidades vegetais. Solos e vegetação foram amostrados em oito parcelas replicadas dentro de cada um dos quatro tipos de vegetação. Amostras de solo superficiais $(0-10 \mathrm{~cm})$ de cada parcela foram analisadas para cátions básicos, $\mathrm{N}, \mathrm{P}$ e densidade de espécies de plantas para todas as espécies foram registradas. Análise de ordenação CCA evidenciou uma forte separação entre áreas florestais e não florestais no primeiro eixo, e entre campo rupestre herbáceo e arbustivo no segundo eixo. Os quatro tipos de vegetação compartilham poucas espécies de plantas, o que pode ser atribuído aos seus ambientes de solos distintos e filtragem de suas espécies constituintes por limitações químicas, físicas e hidrológicas. Assim, podemos inferir que fatores edáficos (pedológicos) são cruciais para explicar os tipos e distribuições da vegetação dos campos rupestres associados com platôs ferruginosos (Canga), em Carajás, no leste da Amazônia, sendo, portanto, as propriedades do solo as principais condutoras da composição e estrutura da vegetação nestas ilhas ferríferas.

Palavras-chave: Floresta Amazônica, canga, Carajás, campo rupestre ferruginoso, formações ferruginosas, laterita.

\section{REFERENCES}

AB'SABER AN. 1986. Geomorfologia da Região. In: Almeida JR (Org), Carajás: desafio político, ecologia e desenvolvimento. Chapter 5. Brasiliense, p. 88-124.

BARROS NF. 1979. Growth and foliar nutrient concentrations of Eucalyptus grandis in relation to spodasol properties in South Florida. Ph.D. Dissertation, University of Florida, Gainsville.

BORCARD D, GILLET F AND LEGENDRE P. 2011. Numerical Ecology with R. Springer, New York Dordrecht London Heidelberg, $306 \mathrm{p}$.

BOTREL RT, OLIVEIRA-FILHO AT, RODRIGUES LA AND CURI N. 2002. Influencia do solo e topografia sobre as variações da composição florística e estrutura da comunidade arbóreo-arbustiva de uma floresta estacional semidecidual em Ingaí, Mg. Rev Bras Bot 25: 195-213.

BUTCHER R, BYRNE M AND CRAYN DM. 2007. Evidence for convergent evolution among phylogenetically distant rare species of Tetratheca (Elaeocarpaceae formerly Tremandraceae) from Western Australia. Aust Syst Bot 20: 126-138.

ChIARUCCI A, ENRIGHT NJ, PERry GL W, Miller BP AND LAMONT BB. 2003. Performance of non parametric species richness estimators in high diversity plant communities. Divers Distrib 9: 283-295. 
EMBRAPA - EMPRESA BRASILEIRA DE PESQUISA AGROPECUÁRIA. 1997. Manual de métodos de análise de solo. Ed.2. Rio de Janeiro, National Research Center for Soil.

FORZA RC ET AL. 2012. Lista de espécies da flora do Brasil. Jardim Botânico do Rio de Janeiro, Rio de Janeiro. Available at: http://floradobrasil.jbrj.gov.br/2012.

GIBSON N. 2004a. Flora and vegetation of the eastern Goldfields ranges: Part 6. Mt Manning Range. J R Soc West Aust 87: 35-47.

GIBSON N. 2004b. Flora and vegetation of the eastern Goldfields ranges: Part 7. Middle and south Ironcap, Digger Rock and Hatter Hill. J R Soc West Aust 87: 49-62.

GIBSON N, MEISSNER R, MARKEY AS AND THOMPSON WA. 2012. Patterns of plant diversity in ironstone ranges in arid south Western Australia. J Arid Environ 77: 25-31.

Gibson N, YATES CJ AND Dillon R. 2010. Plant communities of the ironstone ranges of South Western Australia: hotspots for plant diversity and mineral deposits. Biodivers Conserv 19: 3951-3962.

GLEDHILL D. 1970. The vegetation of superficial ironstone hardpans in Sierra Leone. J Ecol 58: 265-274.

HARLEY RM AND SIMMONS NA.1986. Florula of Mucugê, Chapada Diamantina - Bahia, Brazil. R Bot Gard Kew.

IBAMA - INSTITUTO BRASILEIRO DO MEIO AMBIENTE E DOS RECURSOS NATURAIS RENOVÁVEIS, CVRD COMPANHIA VALE DO RIO DOCE AND STCP - STCP Engenharia DE PRojetos LTDA. 2003. Plano de manejo para uso múltiplo da Floresta Nacional de Carajás.

JACOBI CM AND DO CARMO FF. 2011. Life-forms, pollination and seed dispersal syndromes in plant communities on ironstone outcrops, SE, Brazil. Act Bot Bras 25: 395-412.

JACOBI CM, DO CARMO FF AND VINCENT RC. 2008. Estudo Fitossociológico de uma comunidade vegetal sobre canga com subsídio para a reabilitação de áreas mineradas no Quadrilátero Ferrífero, MG. Rev Arv 32: 345-353.

JACOBI CM, DO CARMO FF, VINCENT RC AND STEHMANN JR. 2007. Plant communities on ironstone outcrops: a diverse and endangered Brazilian ecosystem. Biodivers Conserv 16: 2185-2200.

LEGENDRE P AND GALLAGHER E. 2001. Ecologically meaningful transformations for ordination of species data. Oecol 129: 271-280.

MARKEY AS AND DILLON SJ. 2008. Flora and vegetation of the banded iron formations of the Yilgarn Craton: the central Tallering Land System. Conserv Sci West Aust 7: 121-149.

MARKEY AS AND DILLON SJ. 2009. Flora and vegetation of the banded iron formations of the Yilgarn Craton: Herbert Lukin Ridge .Wiluna. Conserv Sci West Aust 7: 391-412.

MARKEY AS AND DILLON SJ. 2010. Flora and vegetation of the banded iron formations of the Yilgarn Craton: Gullewa. Conserv Sci West Aust 7: 531-556.
MCCUNE B AND GRACE JB. 2002. Analysis of ecological communities. Mjm Software Design, Gleneden Beach, OR, US.

MCCUNE B AND MEFFORD MJ. 2011. PC-ORD Multivariate analysis of ecological data. Version 6.MjM Software Desing, Glaneden Beach, Oregon, USA.

MeIRELles ST, MatTos EA AND Silva AC. 1997. Potential desiccation tolerant vascular plants from southeastern Brazil. Pol J Environ Stud 6: 17-21.

MEISSNER R AND CARUSO Y. 2008. Flora and vegetation of banded iron formations of the Yilgam Craton: Koolanooka and Pernjori Hills. Conserv Sci West Aust 7: 73-88.

MEISSNER R, OWEN G AND BAYLISS B. 2009. Flora and vegetation of the banded iron formation of the Yilgarn Craton: Robinson Ranges and Mount Gould. Conserv Sci West Aust 7: 363-376.

MEISSNER R AND WRIGHT J. 2010. Flora and vegetation of banded iron formations on the Yilgarn Craton: south Illaara Greenstone Belt. Conserv Sci West Aust 7: 605-616.

Messias MCTB, LeITE MGP, MEIRA Neto JA, Kozovits AR AND TAVARE R. 2013. Soil-Vegetation Relationship in Quartzitic and Ferruginous Brazilian Rocky Outcrops. Folia Geobotanica 48: 509-521.

Morelato PC AND RosA NA. 1991. Caracterização de alguns tipos de vegetação na região amazônica, Serra dos Carajás, Pará. Brasil. Rev Bras Bot 14: 1-14.

Mueller-Dombois DY AND Ellenberg H. 1974. Aims and methods in vegetation ecology. New York: J Wiley \& Sons, $547 \mathrm{p}$.

OKSANEN J, BLANCHET FG, KINDT R, LEGENDRE P, O'HARA RB, Simpson GL, SOlymos P, HENRY M, STEVENS H AND WAGNeR H. 2011. Vegan: Community Ecology. R package, version 1.17-6. http://CRAN.R-project.org/ package vegan.

PAGE D. 2001. Banded iron formations and palaeoenvironment: a problem in petrogenesis. Geo Today 17: 140-143

PERES-NETO PR AND LEGENDRE P. 2010. Estimating and controlling for spatial structure in the study of ecological communities. Glob Ecol Biogeogr 19: 174-184.

PERES-NETO PR, LEGENDRE P, DRAY S AND BORCARD D. 2006. Variation partitioning of species data matrices: estimation and comparison of fractions. Ecology 87: 26142625.

POREMBSKI S, BARTHLOTT W, DORRSTOCK S AND BIEDINGER N. 1994. Vegetation of rock outcrops in Guinea: granite inselbergs, sandstone table mountains and ferricretes - remarks on species numbers and endemism. Flora 189: 315-326.

PORTO ML AND SILVA MFF. 1989. Tipos de Vegetação Metalófila em Áreas da Serra de Carajás e de Minas Gerais, Brasil. Act Bot Bras 3: 13-21. 
QUEIROZ LP, SENA TSN AND COSTA MJSL. 1996. Flora vascular da Serra da Jibóia, Santa Terezinha, Bahia. I: O campo rupestre. Sitientibus 15: 27-40.

R DeVelopment Core TEAm. 2011. R: A language and environment for statistical computing. 2.12.1 Vienna, Austria, R Foundation for Statistical Computing. http:// www.R-project.org.

RIZZINI CT. 1979. Tratado de Fitogeografia do Brasil: Aspectos sociológicos e florísticos. Ed. of the Humanism, Science and Technology, São Paulo State, Brazil. Vol 2.

SARCINELLI TS, SCHAEFER CEGR, LYNCH LS, ARATO HD, ViAnA JHM, AlBUQUERQUE FILHo MR AND GONÇALVES TT. 2009. Chemical, physical and micromorphological properties of termite mounds and adjacent soils along a toposequence in Zona da Mata, Minas Gerais State, Brazil. Catena 76: 107-113.

SCHAEFER CEGR, SIMAS FNB, MENDONÇA BAF, SABOYA AS, FERREIRA JÚNIOR WG, NUNES JA AND CORREA GR. 2009. Geodiversidade dos Ambientes de Canga na Região de Carajás- Pará. Technical Report. part 2., Vale Brazilian Company.

SECCO RS AND MESQUITA AL. 1983. Nota sobre a vegetação de Canga da Serra Norte. I. Bol Mus Para Emílio Goeldi Bot 59: 1-13.

SEMIR J. 1991. Revisão taxonômica de Lychnophora Mart. Vernoniaceae: Compositae. Ph.D. Dissertation, Campinas University, São Paulo State, Brazil.

SILVA MFF. 1992. Distribuição de metais pesados na vegetação metalófila de Carajás. Act Bot Bras 6: 107-122.

SILVA MFF AND RoSA N. 1990. Estudos Botânicos na Área do Projeto Ferro de Carajás, Serra Norte. I - Aspectos ecológicos e vegetacionais dos campos rupestres. In: Congresso Nacional de Botânica, 35, Manaus. Soc Bras de Bot, p. 367-379.

STATSOFT INC. 2003. Statistica. Data analysis software system., Version 6, Tulsa, Oklahoma: www.statsoft.com.

TEIXEIRA WA AND LEMOS-FILHO JP. 1998. Metais pesados em folhas de espécies lenhosas colonizadoras de uma área de mineração de ferro em itabirito. Minas Gerais. Rev Árv 22: 381-388.

TEIXEIRA WA AND LEMOS-FILHO JP. 2002. Fatores edáficos e a colonização de espécies lenhosas em uma cava de mineração de ferro em Itabirito, Minas Gerais. Rev Árv 26: 25-33.

TER BRAAK CJF. 1987. The analysis of vegetation environment relationship by canonical correspondence analysis. Vegetation 69: 69-77.

TER BRAAK CJF. 1994. Canonical community ordination. Part I: basic theory end TER BRAAK CJF. Ordination. 1995. In: Jongman RHG, Ter Braak CJF and Van Tongeren OFR
(Eds), Data analysis in community and landscape ecology. Cambridge: Cambridge University Press, p. 91-173.

TER BRAAK CJF. 1995. Ordination. In: Jongman RHG, Ter Braak CJF and Van Tongeren OFR (Eds), Data analysis in community and landscape ecology. Cambridge: Cambridge University Press, p. 91-173.

TER BRAAK CJF AND ŠMilauer P. 2002. CANOCO Reference manual and CanoDraw for Windows user's guide: Software for Canonical Community Ordination. version 4.5. Ithaca, Microcomputer Power.

VALENTIN C, HeRbes JM AND POESEN J. 1999. Soil and water components of banded vegetation patterns. Catena 37: 1-24.

VELOSO HP, RANGEL FILHO ALR AND LIMA JCA. 1991. Classificação da vegetação brasileira, adaptada a um sistema universal. Rio de Janeiro: IBGE, Departamento de recursos Naturais e Estudos Ambientais, 124 p.

VIANA PL AND LOMBARDi JA. 2007. Florística e Caracterização dos Campos Rupestres sobre Canga na Serra da Calçada, Minas Gerais, Brasil. Rodriguesia 58: 159-177.

VINCENT RC. 2004. Florística, fitossociologia e relações entre a vegetação e o solo em área de campos ferruginosos no Quadrilátero Ferrífero, Minas Gerais. Ph.D. Dissertation, São Paulo University, São Paulo.

VinCENT RC, JACOBI CM AND ANTONini Y. 2002. Diversidade na adversidade. Ciênc Hoje 31: 64-67.

VINCENT RC AND MEGURO M. 2008. Influence of soil properties on the abundance of plant species in ferruginous rocky soils vegetation, southeastern Brazil. Rev Bras Bot 31: 377-388.

YATES CJ, Gibson N, PeTtit NE, Dillon R AND PALMER R. 2011a. The ecological relationships and demography of restricted ironstone endemic plant species: implications for conservation. Aust J Bot 59: 692-700.

YATES CJ, LADD PG, COATES DJ AND MCARTHUR S. 2011b. Hierarchies of cause: understanding rarity in an endemic shrub Verticordia staminosa. Myrtaceae with a highly restricted distribution. Aust J Bot 55: 194-205.

ZAR JH. 1996. Biostatistical Analysis. New Jersey, Prentice Hall. $3^{\text {rd }}$ Ed.

\section{SUPPLEMENTARY MATERIAL}

TABLE SI - Total density of plant species recorded in each vegetation type at Serra Sul, Serra dos Carajás, Pará State, Brazil. $\mathbf{H C R}=$ herbaceous campo rupestre; $\mathrm{SCR}=$ shrubby campo rupestre; $\mathrm{CF}=$ capão forest; $\mathrm{MF}=$ montane forest. 